\title{
Degradation of PCB congeners by bacterial strains
}

Rein, A.; Fernqvist, M.M.; Mayer, Philipp; Trapp, Stefan; Bittens, M.; Karlson, U.G.

\section{Published in:}

Applied Microbiology and Biotechnology

Link to article, DOI:

10.1007/s00253-007-1175-6

Publication date:

2007

Link back to DTU Orbit

Citation (APA):

Rein, A., Fernqvist, M. M., Mayer, P., Trapp, S., Bittens, M., \& Karlson, U. G. (2007). Degradation of PCB congeners by bacterial strains. Applied Microbiology and Biotechnology, 77(2), 469-481.

https://doi.org/10.1007/s00253-007-1175-6

\section{General rights}

Copyright and moral rights for the publications made accessible in the public portal are retained by the authors and/or other copyright owners and it is a condition of accessing publications that users recognise and abide by the legal requirements associated with these rights.

- Users may download and print one copy of any publication from the public portal for the purpose of private study or research.

- You may not further distribute the material or use it for any profit-making activity or commercial gain

- You may freely distribute the URL identifying the publication in the public portal

If you believe that this document breaches copyright please contact us providing details, and we will remove access to the work immediately and investigate your claim 


\section{Degradation of PCB congeners by bacterial strains}

\section{- Determination of kinetic parameters and modelling of rhizoremediation}

Appl Microbiol Biotechnol DOI 10.1007/s00253-007-1175-6 vol 77 469-481

Arno Rein ${ }^{(1) *}$, Margit M. Fernqvist ${ }^{(2)}$, Philipp Mayer ${ }^{(2)}$, Stefan Trapp ${ }^{(3)}$, Martin Bittens ${ }^{(1)}$, Ulrich Gosewinkel Karlson ${ }^{(2)}$

(1) Helmholtz Centre for Environmental Research - UFZ, Permoserstr. 15, 04318 Leipzig, Germany

(2) National Environmental Research Institute, University of Aarhus, PO Box 358, DK-4000 Roskilde, Denmark

(3) Institute of Environment \& Resources DTU, Technical University of Denmark, Bygningstorvet 115, DK-2800 Kongens Lyngby, Denmark

* Corresponding author: e-mail: arno.rein@ufz.de, Phone: +49 341235 2475, Fax: +49 3412352126 


\section{Abstract}

Biological in situ methods are options for the remediation of contaminated sites. An approach to quantify biodegradation by soil bacteria was developed, combining experiment with mathematical modelling. We performed in vitro assays to investigate the potential and kinetics of the wild-type degrader, Burkholderia sp. strain LB400 (expressing bph) and the genetically modified Pseudomonas fluorescens strains $\mathrm{F} 113 \mathrm{pcb}$ and $\mathrm{F} 113 \mathrm{~L}:: 1180$ (expressing bph under different promoters) to metabolise individual congeners of polychlorinated biphenyls (PCBs). Kinetics of metabolism was analysed using the Monod model.

Results revealed similar patterns of degradable PCB congeners for LB400 and F113L::1180. The degree of PCB degradation was comparable for LB400 and F113L::1180, but was much lower for F113rifpcb. In additional mesocosm experiments with PCB contaminated soil, the F113 derivatives demonstrated a good survival ability in willow (Salix sp.) rhizosphere.

Strain F113L::1180 in combination with willow plants is expected to degrade a large spectrum of PCB congeners in soil. The data from the experiments were used to calculate the time scale of the degradation process in a PCB-contaminated soil. The uncertainty of the model predictions due to the uncertainties of experimental removal velocities and bacterial cell density in soil was quantified.

\section{Keywords}

bacteria; cometabolism; genetically modified; biodegradation; modelling; Monod kinetics; PCB; rhizoremediation; soil contamination; willow 


\section{Introduction}

Bioremediation with soil bacteria has been extensively studied during the last few decades, with the goal to clean-up polluted soils. The success of bioremediation depends on the potential to degrade the pollutants, and on the time this will take. Before implementation, biological in situ measures require a detailed and reliable risk analysis. An important objective is to quantify contaminant degradation and metabolite formation. Very often, it is not a single compound, but a mixture of contaminants that causes the problem. An example is the group of polychlorinated biphenyls (PCBs), forming a mixture of up to 209 different congeners.

From 1930 to the late 1980s, PCBs have been widely applied in industrial products and processes. Being persistent, $\mathrm{PCBs}$ are nowadays distributed ubiquitously in the global ecosystem (McFarland and Clarke 1989; Meijer et al. 2003). Unfortunately, PCBs are accumulating in the food web and cause a number of toxic effects to a wide range of organisms (Safe 1994; Bright et al. 1995).

Microbial degradation of PCBs in contaminated soil has been the subject of extensive research (Furukawa and Matsumura 1976; Unterman 1988; Leigh et al. 2006). In the environment, PCBs may be degraded by aerobic bacteria through the biphenyl catabolic pathway, following a cometabolic process (Seeger et al. 1995; Abramowicz 1990). Rhodococci, such as Rhodococcus sp. strain RHA1, are known to be effective PCB degraders surviving well in soil (Masai et al. 1995, Seto et al. 1995, Leigh et al. 2006). Furthermore, many studies centred on Burkholderia sp. LB400 (formerly Pseudomonas sp. LB400) which was isolated from PCB-contaminated soil (Bopp 1986) and oxidises a wide range of PCBs (Bedard et al. 1986; Bedard 1990; Gibson et al. 1993).

Many effective degrader strains revealed a decline in survival and degradation activity after introduction into soil, which limits their applicability for in situ bioremediation. These difficulties can be met by periodic re-inoculation or continuous addition of co-substrate (e.g. biphenyl) (Barriault and Sylvestre 1993). However, the practical importance of such procedures is limited due to technical difficulties (repeated application) or the potential toxicity and low water solubility of biostimulating substances such as biphenyl (e.g. Leigh et al. 2006). An alternative solution might be to insert the bph genes encoding the biphenyl pathway into a bacterial host with high survival capability in specific soil compartments.

The vicinity of plant roots is the preferred environment for soil microorganisms (Aragno 2005; Walton and Anderson 1990). Growing roots may transport inoculated bacteria through soil (Karlson et al. 
1995, Villacieros et al. 2005). Besides forming a habitat and transport system for microorganisms, plant roots also provide substrate supporting the growth of PCB-degrading bacteria (Fletcher and Hedge 1995, Olson et al. 2001). Thus, rhizoremediation, i.e. the use of microbes in conjunction with plants, is a promising bioremediation strategy (Trapp and Karlson 2001; Leigh et al. 2006; Yee et al. 1998). Consequently, efforts were undertaken to expand the degradation capacities of rhizospherecompetent bacteria (Villacieros et al. 2005; Brazil et al. 1995; Yee et al. 1998). A number of plantmicrobe consortia have been tested recently (Ryslava et al. 2003; Demnerova et al. 2005). Pseudomonas fluorescens $\mathrm{F} 113$, which was originally isolated from sugar beet rhizosphere (Shanahan et al. 1992), is an excellent coloniser of several plant rhizospheres, such as those of sugar beet (Shanahan et al. 1992, Delany et al. 2001), tomato (Simons et al. 1996), pea (Naseby and Lynch 1999), alfalfa (Villacieros et al. 2003) and willow (Karlson, unpublished results). Derivatives of strain F113 with rhizoremediation ability were constructed genetically. In a first step, genes encoding the bph pathway were cloned from LB400 and inserted into a transposon (Dowling et al. 1993). Then the bphcassette was chromosomally integrated into F113 to generate F113rifpcb (Brazil et al. 1995) and F113L::1180 (Villacieros et al. 2005).

In this study, we investigated the potential of wild-type Burkholderia sp. strain LB400 and the genetically modified Pseudomonas fluorescens strains F113pcb and F113L::1180 to metabolise PCBs. Different from earlier studies (e.g. Gibson et al. 1993; Villacieros et al. 2005), we quantified the time-scale of bacterial breakdown of PCB in the rhizosphere of contaminated soils, and for commercial mixtures of PCBs (Aroclor 1016, 1221 and 1232). As known by the authors, this is the first publication of Monod parameters for bacterial strains metabolising a wide range of PCBs. Substrate range and the kinetic parameters of the Monod equation were acquired in laboratory experiments (pure culture in vitro resting cell assays) with individual PCB congeners. Data on bacterial mass and on survival in the rhizosphere were determined in mesocosm experiments with contaminated soils and willow trees. Mathematical models were applied to upscale to real contaminated sites. An important aspect was also to analyse the uncertainty of the model predictions due to the uncertainty of the experimental input data. 


\section{Materials and Methods}

\section{$\underline{\text { In vitro biodegradation }}$}

Resting cell assays were performed with the wild-type degrader Burkholderia sp. LB400 (Bopp 1986), (which expresses bph upon induction with biphenyl) the rifampicin resistant root-colonising nondegrader Pseudomonas fluorescens F113rif (Shanahan et al. 1992), and the genetically modified F113 derivatives Pseudomonas fluorescens F113L::1180 (Villacieros et al. 2005) and Pseudomonas fluorescens F113rifpcb (Brazil et al. 1995) (which express bph constitutively under the control of different promoters).

The bacterial cultures were pregrown on biphenyl, except strain F113rif (which served as the negative control) on salicylic acid (SA) medium (minimal medium enriched with $20 \mathrm{~g} / \mathrm{L}$ sucrose and $2 \mathrm{~g} / \mathrm{L}$ asparagine). The bacteria were diluted in minimal medium to an $\mathrm{OD}_{600}$ (optical density at $600 \mathrm{~nm}$ ) of around 0.4 , corresponding to approximately $1.5-2 \times 10^{11}$ cells/L. PCBs were supplied by Dr. Ehrenstorfer GmbH, Augsburg, Germany (IUPAC No. 10, 16, 17, 18, 20, 25, 34, 37, 41, 47, 66, 69, 70, 74, 87) and Riedel-de Haën, Seelze, Germany (IUPAC No. 1, 2, 3, 4, 5, 15, 28, 31, 52, 77, 101, 153). PCB was dissolved in acetone and spiked into the medium, to yield a final concentration of $5 \mu \mathrm{mol} / \mathrm{L}$. Bacterial incubation was performed immediately following the PCB spike.

For all PCBs with IUPAC No. 16 or higher (Table 1), the spiked concentrations exceeded the aqueous solubility. This implies a freely dissolved concentration $\left(C_{f r e e}\right)$ that equals aqueous solubility, which is equivalent to the maximum chemical activity (a) of the respective PCB congener (Reichenberg and Mayer 2006). Bacterial cells within the aqueous solution were thus exposed to the freely dissolved PCB concentration, whereas non-dissolved PCB could become accessible upon dissolution. It is, therefore, necessary to distinguish between the effective concentration for uptake and biodegradation $\left(C_{\text {free }}\right)$ and the total accessible concentration $\left(C_{\text {total }}\right)$.

The reduction of total accessible concentration of individual PCB congeners was measured versus time, using headspace-SPME and GC/ECD. Prior to measurement, the biodegradation was stopped and all PCBs were brought into solution by mixing the culture sample with $20 \% \mathrm{EtOH}+0.1 \%$ Triton-X100. The vials were then put in an autosampler tray and total residual PCB concentrations were determined by headspace SPME-GC/ECD (adapted from Legind et al 2007). In the negative control, disappearance was assumed to be due to abiotic degradation of the PCB substrate. Because of 
analytical constraints, production of metabolites was not determined in this assay. In total, the degradation of 29 PCB congeners was investigated.

12 to 16 measurements per assay were carried out with degrader bacteria (strains LB400, F113L::1180, F113rifpcb; duplicates at the beginning and in the end for most experiments) and 6 for each negative control (strain F113rif; 3 duplicate measurements each at the beginning and in the end). For data analysis, contaminant loss due to processes other than biodegradation has to be taken into account, e.g. potential evaporation from the vial (especially for low chlorinated PCB congeners). Where necessary, concentrations measured in vials with degrader bacteria were corrected by subtracting the depletion observed in negative controls. For corrections, the negative control was assumed to decline linearly.

\section{Estimation of initial bacterial mass and numbers}

Initial bacterial mass $B_{0}$ was estimated from optical density $\left(O D_{600}\right)$ measurements taken for the individual experiments:

$$
\begin{array}{ll}
B_{0}=C F \times O D_{600} & \text { (1) } \quad \text { initial bacterial mass, total protein }[\mathrm{g} / \mathrm{L}] \\
C F: \text { conversion factor }[\mathrm{g} / \mathrm{L}] \\
O D_{600} \text { : optical density of liquid medium at } 600 \mathrm{~nm} \mathrm{[-]}
\end{array}
$$

The conversion factor $C F$ was established by analysing one experimental culture of each bacterial strain in triplicate, using a commercial protein determination kit and bovine serum albumin as a standard. Bacterial numbers were determined as colony forming units (CFU) on LB plates. Culture purity was ascertained by streaking on LB plates.

\section{Bacterial survival and growth in mesocosm experiments}

Plant-soil mesocosm studies were conducted in the laboratory in order to elucidate the fate of F113 derivatives in phytoremediation of contaminated soil. PCB-contaminated soil from a dump site near Lhenice, Czech Republic, was used for the experiments. The studies involved the inoculants F113rif, F113rifpcb and F113L::1180.

Two- to three-week old willow cuttings (Salix viminalis $x$ schwerinii) were inoculated by dipping the roots in bacterial suspensions for 1 hour. The number of bacteria in suspension was approximately $10^{6}$ $\mathrm{cfu} / \mathrm{mL}$. The willows then were planted into zinc pots. Sieved soil material $(2 \mathrm{~kg}$ soil per pot) was 
poured around the roots. Rhizosphere was sampled at 4-week intervals over a total period of 7 months, soil was sampled at the end of the experiment. For bulk soil samples, undisturbed cores were taken. For rhizosphere samples, whole plants were removed from the mesocosms, soil adhering to the roots was shaken off and roots with residual soil were collected using sterile scissors and forceps. Except for total viable counts, all samples were frozen immediately and maintained at $-20 \stackrel{\circ}{ } \mathrm{C}$ until analysis. Bacterial numbers were determined as CFU on 10\%TSA plates and on selective SArif plates. Evaluation of degradation capacity and kinetics

The PCB metabolism studied in the experiments is characterised by a cometabolic process. Cometabolism describes the transformation of a non-growth substrate while the microbes feed on a growth or energy substrate. Cometabolism, therefore, is based on low specificity of enzymes and cofactors (Horvath 1972; Dalton and Stirling 1982). In the above definition, substrates are electron donors providing reductive power and energy. A growth substrate enables cell growth and maintenance, whereas an energy substrate does not by itself support growth. Experimental observations indicate that for growing cells, the rates of cometabolic transformations are linked to the consumption of a growth substrate. In the absence of a growth substrate (i.e. for resting cells), the transformation rates are coupled to the consumption of cell mass and/or energy substrate (Criddle 1993). Accordingly, the kinetics of PCB degradation can be described by Monod kinetics, considering bacterial growth or decay (e.g. Trapp et al. 2007):

\footnotetext{
B: bacterial mass $[\mathrm{mg}]$

$\frac{d B}{d t}=\frac{\mu_{\max } \times C \times B}{K_{S}+C}-k_{\text {death }} \times B$

(2) $\quad \mu_{\text {max }}$ : maximum growth rate of bacteria $[1 / \mathrm{h}]$

C: substrate concentration $[\mathrm{mg} / \mathrm{L}]$

$K_{S}$ : half-growth concentration (concentration where the growth is half of the maximum) $[\mathrm{mg} / \mathrm{L}]$

$k_{\text {death }}$ : first order rate describing the decline of active bacterial cells $[1 / h]$
}

During growth, the bacteria metabolise the substrate. The substrate mass balance is set up as follows (according to Trapp et al. 2007; Cornish-Bowden 1995):

$\frac{d m}{d t}=-\frac{v_{\max } \times C}{K_{M}+C} \times B \quad$ (3) $\quad m$ : substrate mass [mg] 


$$
\begin{aligned}
& v_{\max }: \text { maximal substrate removal velocity per bacterial mass } \\
& {\left[\mathrm{mg} \mathrm{h}^{-1} \mathrm{mg} \text { bacteria }^{-1}\right]} \\
& K_{M}: \text { half-saturation constant }[\mathrm{mg} / \mathrm{L}]
\end{aligned}
$$

Considering the initial bacterial mass in the experiments, Eq. (3) modifies to:

$$
\begin{gathered}
\frac{d m}{d t}=-\frac{v_{\max }^{*} \times C}{K_{M}+C} \times \frac{B}{B_{0}} \quad \text { (4) } \quad v_{\text {max }}^{*}[\mathrm{mg} / \mathrm{h}]: \text { maximal removal velocity related to initial bacterial mass } \\
B_{0}[\mathrm{mg}], \text { with } v_{\text {max }}^{*}=v_{\max } \times B_{0}
\end{gathered}
$$

If the sustrate does not support growth, $\mu_{\max }$ is zero and only decay of active microbes is presumed. Then, the respective term in Eq. (2) eliminates:

$\frac{d B}{d t}=-k_{\text {death }} \times B$

From the data set consisting of measured and corrected concentrations, parameters for Monod kinetics were determined with Eq. (4) and (5). This model is consistent with an approach presented by Criddle (1993).

For the fit of the kinetic parameters, measured PCB concentrations were used for the lower chlorinated congeners (PCB with IUPAC-No. 1 to 5), which were below $S$ in all experiments. For PCBs with IUPAC-No. 16 or higher, the aqueous solubility $(S)$ was set to be the maximum effective substrate concentration $(C)$ in Eq. (4)

Three unknown variables were required: $v_{\max }^{*}, K_{M}$ and $k_{\text {death. }}$. The estimation of these variables was performed in two steps: a) approximation of $V_{\max }^{*}$ and $K_{M}$ at the initial phase of the experiment, b) adjustment of $k_{\text {death }}$ by least square fit. An iterative procedure was performed to adjust the parameters. Beside the evaluation of most probable model curves, uncertainty was addressed by fitting minimum and maximum curves to the measured data. Automated curve-fitting procedures included in the Life Science Workbench (LSW) Data Analysis Toolbox (add-in program for Microsoft Excel) were used.

\section{Modelling of degradation under field conditions}

To estimate degradation kinetics under field conditions, initial bacterial numbers from the in vitro experiments and bacterial numbers observed in rhizosphere (mesocosm test with contaminated soil) were considered. For a potentially reduced degradation performance under field conditions, a factor 
$f_{R D}[-]$ is introduced. The Monod parameters $v^{*}$ max and $K_{M}$ were scaled to initial experimental substrate mass and concentration to obtain $k^{*}{ }_{\max }$ and $K_{M}{ }^{*}$ :

$$
\begin{array}{lll}
k_{\max }^{*}=\frac{v_{\max }^{*}}{m_{0}} & \text { (6) } & k_{\text {max }}^{*}: \text { maximum removal rate }[1 / \mathrm{h}] \\
& m_{0}: \text { initial experimental substrate mass [mg] } \\
K_{M}^{*}=\frac{K_{M}}{C_{0}} & \text { (7) } \quad \begin{array}{l}
K_{M}{ }^{*}: \text { dimensionless half-saturation constant [-] } \\
C_{0}: \text { starting concentration in laboratory [mg/L] }
\end{array}
\end{array}
$$

In analogy to the evaluation of degradation kinetics, the freely dissolved concentration $\left(C_{\text {free }}\right)$ was considered the effective concentration for the biodegradation process. This does not restrict the biodegradation process to only take place in the water phase, since the desorption from the soil matrix is driven by the chemical activity that is proportional to $C_{\text {free }}$ (Reichenberg and Mayer 2006). Inserting Eq. (6) and (7) into Eq. (4) (i.e., utilising Monod parameters that are scaled to dimensionless mass and concentration) and considering relative values for soil water concentration (normalised units), the removal of substrate mass in soil can be calculated as:

$$
\begin{aligned}
\frac{d m_{S}}{d t}=-\frac{k_{\max }^{*} \times C_{S W} / C_{S W, 0}}{K_{M}^{*}+C_{S W} / C_{S W, 0}} \times m_{S, 0} \times \frac{B_{s o i l}}{B_{0}} \times f_{R D}^{-1} \text { (8) } \quad & B_{0} \text { : initial bacterial mass in laboratory [mg] } \\
& B_{s o i l} \text { bacterial mass in soil [mg] } \\
& m_{S}, m_{S, 0} \text { : mass, initial mass in soil [mg] } \\
& C_{S W}, C_{S W, 0} \text { : concentration, initial concentration } \\
& \text { in soil solution [mg/L] }
\end{aligned}
$$

with

$$
C_{S W}=\frac{\rho_{\text {wet }}}{K_{s w}} \times C_{S}
$$

$$
C_{S} \text { : soil concentration }[\mathrm{mg} / \mathrm{kg}]
$$$$
K_{\text {Sw: }} \text { soil-water partition coefficient [L/L] }
$$

where

$$
\begin{array}{ll}
\rho_{\text {wet }}=\rho_{\text {dry }}+\theta_{w s} \times \rho_{W} & (10) \quad \\
& \rho_{\text {wet: }} \text { wet soil density }[\mathrm{kg} / \mathrm{L}] \\
& \rho_{\text {dry }}: \text { dry soil density }[\mathrm{kg} / \mathrm{L}] \\
& \rho_{w}: \text { water density }[\mathrm{kg} / \mathrm{L}]\left(\rho_{\mathrm{W}}=1 \mathrm{~kg} / \mathrm{L} \text { assumed }\right) \\
& \theta_{w s}: \text { water saturation }\left[\mathrm{m}^{3} / \mathrm{m}^{3}\right]
\end{array}
$$


For the determination of the soil-water partition coefficient, adsorption to soil particles was treated as a linear organic carbon relationship, which was assumed to hold as an approximation for most moist soils (Fetter 1994):

$K_{S w}=f_{O C} \times K_{O C} \times \rho_{d r y}+\theta_{w s}$

$$
\begin{aligned}
& f_{O C}: \text { fraction of soil organic carbon }[\mathrm{g} / \mathrm{g}] \\
& K_{O C} \text { : organic carbon partition coefficient }[\mathrm{L} / \mathrm{kg}]
\end{aligned}
$$

The organic carbon partition coefficient $K_{O C}$ was estimated from the octanol-water partition coefficient Kow as recommended by EC (1996):

$K_{\text {OC }}=0.81 \times K_{\text {ow }}+0.1$

$$
K_{\text {ow: }} \text { octanol-water partition coefficient [-] }
$$

If microbial numbers are considered instead of bacterial mass, Eq (8) is rewritten:

$\frac{d m_{S}}{d t}=-\frac{k_{\max }^{*} \times C_{S W} / C_{S W, 0}}{K_{M}^{*}+C_{S W} / C_{S W, 0}} \times m_{S, 0} \times \frac{C F U_{s o i l}}{C F U_{l a b, 0}} \times f_{R D}^{-1}$

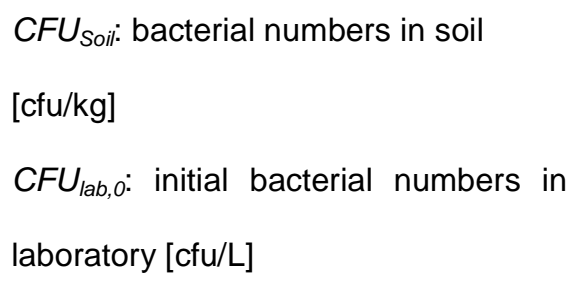

A $f_{R D}$ of 1 indicates that the degradation performance of bacteria in the field is identical to that in the laboratory. In contrast, a $f_{R D}>1$ corresponds to slower degradation in the field (e.g., reduced by a factor of 2 for $f_{R D}=2$ ), which could be caused by interactions between different PCB congeners, impact of toxic compounds present at a contaminated site, reduced nutrient supply (e.g., oxygen, root exudates), reduced substrate availability (aging) or lower temperature.

\section{Results}

\section{Degradation capacity of PCB congeners}

The experimental combinations of PCB congeners and bacterial strains are listed in Table 1. Not all of the tested congeners were metabolised by all strains, but patterns were similar for LB400 and F113L::1180. Out of 25 congeners tested with LB400, 15 were metabolised; 14 out of 26 by F113L::1180 and 3 out of 7 by F113rifpcb. 
In Table 2, the percentage of PCB-depletion observed at the end of the experiments is given. The indicated ranges (minimum and maximum) result from measurement uncertainty, i.e. duplicate measurements at the beginning and at the end of the assay. In cases where the negative control showed a clear decreasing tendency, degradation experiments were corrected accordingly (section Materials and methods, subsection In vitro biodegradation). Most results reflect either clear presence or clear absence of biodegradation. In 4 experiments, depletion rates (uncorrected values) were between 10 and $20 \%$ which cannot be assigned to biodegradation, as contaminant loss observed for the negative control was up to $26 \%$. Corrections were required for lower chlorinated PCBs, which is in accordance to the assumption of compound loss by evaporation. Depletion of the negative control is indicated in Table 2, as well. Corrections were made as shown here for PCB 4 degradation with strain F113L::1180: initial concentration $\mathrm{C}_{0}=1 \mathrm{mg} / \mathrm{L} ; \mathrm{C}$ (measured) after $17.8 \mathrm{~h}=0.06 \mathrm{mg} / \mathrm{L}$; depletion of the negative control $=12 \%(17.8 \mathrm{~h}) ; \mathrm{C}$ (corrected) after $17.8 \mathrm{~h}=0.06 \mathrm{mg} / \mathrm{L} \times 1.12=0.07 \mathrm{mg} / \mathrm{L}$. Accordingly, the corrected percentage of depletion (Depl. in Table 2) is 93\%.

In most cases, strain LB400 had the highest degradation capacity, and in some cases strain F113L::1180. Strain F113rifpcb generally showed the lowest depletion percentages. Differences between LB400 and F113L::1180 were within 3 to $17 \%$ of depletion in most cases (Table 2). Variations between tests with one given strain were up to $16 \%$. The largest differences between strains were seen for PCB 41 (higher rate for F113L::1180, by 46\% of depletion) and PCB 52 (higher rate for LB400, by $60 \%$ of depletion). Differences between mean and maximum or minimum ranged from 1 to $9 \%$, except depletion of PCB 4 by strain F113rifpcb (difference of $25 \%$ ).

\section{Degradation potential for PCB mixtures}

In the past, PCBs were applied as technical mixtures for different applications and released into the environment. As low and moderately chlorinated PCBs are readily degraded by the studied microbes, the potential to metabolise the commercial mixtures Aroclor 1016, 1221 and 1232 (low degree of chlorination) was analysed. This was done by considering the percentage of individual PCB congeners that were measured in these mixtures by Albro and Parker (1979) and Frame et al. (1996).

About 30 to $45 \%$ of the PCB congeners reported for Aroclor 1016 (A1016) were potentially degradable by LB400 and F113L::1800, whereas PCB congeners representing about 10 to $25 \%$ of A1016 were non-degradable. The remaining percentage is composed of congeners which were not investigated in our study. $60-70 \%$ of $A 1221$ and $44-50 \%$ of $A 1232$ potentially can be metabolised versus $5-6 \%$ and 
$13-15 \%$ of respective mixtures being recalcitrant to degradation by strains F113L::1180 and LB400, with lower percentages for the latter. The variations reflect ranges of reported congener fractions, as well as differences in the depletion potential between the strains, where F113L::1180 showed a slightly enhanced degradation potential compared to strain LB400 $(3 \%, 10 \%, 5 \%$ higher percentage of depletion for F113L::1180 and A1016, A1221, A1232, respectively).

\section{In vitro degradation kinetics}

With time, the degradation velocity decreased in all assays, as shown for PCB 4 with strain F113L::1180 (Fig. 1). This was most likely due to a decrease of active bacterial mass (Fig. 1b), as discussed below. Data from all assays are summarised in Table 2.

Beside best estimate model curves, possible ranges due to a) measurement uncertainty in the degradation assays, and b) uncertain water solubility were evaluated. The latter contribution is relevant for PCBs with IUPAC-No. $\geq 16$ only (section Materials and methods, subsection Evaluation of degradation capacity and kinetics). Table 1 indicates likeliest, minimum and maximum values of water solubility that were used for curve fitting. These data were taken from Rein and Bittens (in prep.) who performed a literature survey and generated an internally consistent data set of physicochemical properties of PCBs. The likeliest values were derived from an adjustment procedure based upon thermodynamic constraints (Rein and Bittens in prep.).

The applied procedure of keeping $K_{M}$ constant and varying $v_{\max }^{*}$ with subsequent adjustment of $k_{\text {death }}$ proved appropriate in evaluating reasonable model curves for PCB 1 to 5 . In contrast, for PCBs $\geq 16$, both $V^{*}{ }_{\max }$ and $K_{M}$ had to be varied to derive plausible curve fits. For these congeners, it was found that measurement uncertainty could be described by adjusting $v_{\text {max }}^{*}$, and uncertainty of water solubility $S$ by adjusting $K_{M}$. Mean, upper and lower estimates for degradation kinetics were defined accordingly (Table 2): upper estimate: maximum $v_{\max }^{*}$ and minimum $k_{\text {death }}$, minimum $K_{M}$ if indicated, otherwise mean $K_{M}$; lower estimate: minimum $v_{\max }^{*}$ and maximum $k_{\text {death }}$, maximum $K_{M}$ if indicated, otherwise mean $K_{M}$. An example for obtained upper and lower curves is shown in Fig. 1.

The uncertainty of $K_{M}$ was higher than that of $V_{\text {max }}^{*}$ in most cases. The estimates of water solubility $S$ varied between 30 and $70 \%$ for most congeners, and up to 200\% for PCB 16 and 52 ([maximum minimum] divided by the likeliest value; Table 1), which resulted in a similar range for corresponding $K_{M}$ adjustments (significantly lower for PCB 16: variation about $80 \%$; Table 2). The maximum removal 
velocity $V_{\text {max }}^{*}$ varied between 10 and $30 \%$ for most assays, however up to $60 \%$ for PCB 41,69 and 101.

In addition to first-order decline of active bacterial cells (Eq. 5), linear decay was analysed. Nevertheless, best curve fits were obtained by using the first-order assumption. The results show that $k_{\text {death }}$ increases with $v_{\text {max }}^{*}$. A highly significant linear correlation exists $(p<0.001$, bivariate Pearson correlation). The data is more scattered for F113L::1180 compared to LB400, but the general trend is very similar (Fig. 2a). Considering data for all bacterial strains, the regression between $k_{\text {death }}$ and $v_{\text {max }}^{*}$ is (Fig. 2b):

$k_{\text {death }}=0.082+0.49 \times v_{\max }^{*} \quad(10) \quad\left(\mathrm{N}=39, \mathrm{R}^{2}=0.94\right)$

To obtain consistent results, the correlations were adjusted iteratively. For some experiments with high measurement uncertainty (scattered data), the estimation of Monod parameters was repeated considering the dependence between $k_{\text {death }}$ and $v_{\max }^{*}$.

\section{Bacterial survival and growth}

Initial bacterial mass $B_{0}$ and bacterial numbers $C F U_{0}$ for the resting cell assays are indicated in Table 3. Bacterial mass $B_{0}$ was estimated from the conversion factor $C F$ according to Eq. (1). Values of $O D_{600}$ were recorded with a precision of 3 decimal units for each individual experiment (see Table 2) and utilised for modelling. Table 3 shows the specific values for the bacterial strains.

In the mesocosm experiments, the F113 derivatives showed good survial. Bacterial plate counts revealed that the inocula were present in willow rhizosphere for over half a year. Numbers of bacterial cells per pot at the beginning of the experiments are given in Table 3. Results of bacterial plate counts in the rhizosphere over the time period of observation are summarised in Fig. 3 . With time, the roots formed dense mats at the bottom and the sides of the pots. Fig. 3a shows CFU for the total population of heterotrophic microbes, Fig. 3b for the inoculated F113 derivatives. High fluctuations are obvious, which are discussed later. Willow leaves were beginning to turn yellow after 1 month, suggesting nutrient deficiency in the soil. Soil analysis revealed a phosphate deficiency, which was alleviated by fertilisation on day 50. Bacterial numbers determined in bulk soil samples at the end of the experiment (224 days) were lower than those observed in the rhizosphere by a factor of approx. 4, 5 and 20 for F113rif, F113rifpcb and F113L::1180, respectively (data not shown). 


\section{Modelling of PCB degradation in soil}

In order to estimate degradation kinetics at a contaminated site (hypothetical rhizoremediation), the process was modelled with Eq. (13) for the biodegradable PCB congeners. Results of the estimation are presented in this section, considering biodegradation in soil solution only (i.e. neglecting other contaminant loss processes like leaching or volatilisation). The model uses the Monod parameters determined in subsection In vitro degradation kinetics and the findings on microbial survival in willow rhizosphere from the subsection Bacterial survival and growth. The soil data were taken from a Danish reference soil (dry soil density $\rho_{\text {dry }}=1.6 \mathrm{~kg} / \mathrm{L}$, water saturation $\theta_{W s}=0.35 \mathrm{~m}^{3} / \mathrm{m}^{3}$, fraction of soil organic carbon $f_{O C}=0.02 \mathrm{~g} / \mathrm{g}$ ). Octanol-water partition coefficients $K_{O W}$ that were used for the calculation of organic carbon partition coefficients (Eq. 12) are given in Table 1.

For the calculations, maximal removal velocities $v_{\max }^{*}$ and half saturation constants $K_{M}$ from Table 2 were normalised to initial PCB mass and concentration to derive $k_{\max }^{*}$ and $K_{M}{ }^{*}$ (Eqs. (6) and (7), specific to experiment). Initial bacterial numbers in laboratory $C F U_{l a b, 0}$ were taken from Table 3. Constant bacterial mass in soil was presumed, as no clear decline or growth tendency could be deduced from the mesocosm experiments (subsection Bacterial survival and growth).

The average bacterial density in the willow rhizosphere of the mesocosm experiments was approximately $5 \times 10^{5} \mathrm{cfu} / \mathrm{g}$ root fw (fresh weight) for strain F113L::1180 (Fig. 3b). In pure soil, the number of microbes was around 20 times lower (subsection Bacterial survival and growth). The pots were filled with $2 \mathrm{~kg}$ soil fw and contained approximately $100 \mathrm{~g}$ roots (upper estimate). In real soil, the portion of roots is expected to be much lower. Sitte et al. (1991) gives 10 tons of roots per ha (dry weight) for a Central European deciduous forest dominated by oaks and beech-trees. Thus, assuming a mass ratio root to soil for a Central European forest of about 1: 1000 and applying the observed bacterial numbers in root and soil samples from the mesocosm experiments, an average value for bacterial cells of $2.6 \times 10^{7} \mathrm{cfu} / \mathrm{kg}$ soil ( $\mathrm{fw}$ ) was determined as the sum of bacteria on roots plus bacteria in bulk soil:

$C F U_{\text {soil }}($ average $)=5 \times 10^{5} \mathrm{cfu} / \mathrm{g}$ root fw $\times 0.001+2.5 \times 10^{4} \mathrm{cfu} / \mathrm{g}$ soil fw $\times 0.999=2.55 \times 10^{4} \mathrm{cfu} / \mathrm{g}$ $=2.55 \times 10^{7} \mathrm{cfu} / \mathrm{kg}$

In the following, results for the degradation of Aroclor (A) 1016, 1221 and 1232 are presented (optimum conditions with $f_{R D}=1$ ). The scenario of a fresh soil contamination was considered for the 
modelling, i.e. an unaltered congener composition. The modelling was performed on a congener by congener basis, assuming initially $100 \mathrm{mg} / \mathrm{kg}$ for the total concentration of commercial PCB mixture in soil. Initial concentrations of individual congeners were used according to their reported portion in the mixture (subsection Degradation potential for PCB mixtures).

Soil concentrations over time, modelled for strain F113L::1180 and the congeners PCB 18, 2 and 52 in $100 \mathrm{mg} / \mathrm{kg} \mathrm{A1016}$, are shown in Fig. 4a to 4c. PCB 18, the main component in A1016, is degraded after around 700 years (straight black line in Fig. 4a). This is an average estimation, based on mean values for starting concentration $C_{0}$, for $v_{\max }^{*}, K_{M}$ and $C F U_{\text {soil- }}$ Taking into account uncertainty due to the estimation of $v_{\text {max }}^{*}, K_{M}$ and the measurement of $C_{0}$, i.e. using observed and reported ranges, the required time for the depletion is between 500 and 1200 years (see grey area, defined by minimum and maximum curves). Facing, in addition, the uncertainty inherent to bacterial numbers in soil $C F U_{\text {soil, }}$ the hatched area is obtained. Under these assumptions, the compound is degraded after 200 to $>5000$ years. According to the calculations, PCB 2 (Fig. 4b) is depleted much faster (after 70 years by mean estimation), but the uncertainty of $C_{0}$ is higher than for PCB 18. In contrast, PCB 52 is metabolised only slowly (Fig. 4c).

Depletion kinetics estimated for the degradable fraction of Aroclor mixtures are presented in Fig. $4 \mathrm{~d}$ to 4f for strain F113L::1180. After 1000 years, A1016 is nearly totally depleted as a mean approximation, with maximally $14 \mathrm{mg} / \mathrm{kg}$ as upper limit of the uncertainty range (Fig. 4d). In general, A1221 reveals the highest potential of being metabolised by the strains, followed by A1232 and A1016. However, A1221 and A1232 are technical mixtures that were rarely applied, whereas A1016 was frequently used $(1 \%,<1 \%$ and $13 \%$, respectively of total PCB production in the United States 1957-1977, according to Brown 1994).

\section{Discussion}

In the experiments, lowly and moderately chlorinated PCB congeners were readily metabolised by the investigated strains. The strains LB400 and F113L::1180 showed a similar degradation capacity, whereas the percentage of PCB depletion was generally lower for strain F113rifpcb. The low degradation capacity of F113rifpcb can be attributed to a low bph gene expression, as found in an earlier study (Villacieros et al. 2005). However, Villacieros et al. (2005) reported for the technical

mixture Delor 103 that F113L::1180 degraded most PCB congeners to a somewhat greater extent 
than LB400. This was based on all chromatographic peaks evaluated, although many of these peaks correspond to 2 or 3 co-eluting congeners and the results are difficult to compare with our study, which is based on assays with individual congeners. Nevertheless, in the present investigation, strain L::1180 seems to metabolise most PCB congeners to a similar extent as reported by Villacieros et al. (2005), i.e. less than 15\% difference in depletion, except for PCB 101 (30\% vs. 83\% of depletion, present study vs. Villacieros et al. 2005). In contrast, in our investigation, LB400 metabolised most PCBs to a slightly greater extent (up to about $30 \%$ higher) as reported by Villacieros et al. (2005). In the mesocosm experiments, strain F113L::1180, F113rifpcb and F113rif revealed good survival in willow rhizosphere, but bacterial numbers fluctuated more than one order of magnitude in the observation period of 7 months. Changes in the nutritional status of plants might have an effect on the density of the rhizosphere microbiota. Another explanation might be uncertainty associated with sampling, i.e. the numbers may reflect the heterogeneity of microbial density in the rhizosphere. Facing these temporal fluctuations, factors between microbial numbers in soil and rhizosphere, which were determined at the last sampling of the mesocosm study, might be uncertain. However, similarly to our study, Leigh et al. (2006) found naturally occurring PCB degraders in significantly higher numbers in the rhizosphere of several plant species compared to soil (PCB contaminated site). Respective CFU in the rhizosphere of willows (Salix caprea) were about one order of magnitude lower, compared to our study. Thus, results presented here might be an upper estimate for field conditions. We combined experimental results on the quantification of contaminant breakdown (Monod parameters, bacterial mass) and the survival in the root zone with mathematical modelling to estimate the break-down time scale in real contaminated soil of technical mixtures of PCB. Results given in this paper refer to the assumption that the PCB dissolution from the solid form was sufficiently rapid to maintain freely dissolved concentrations at the saturation level. This assumption can be justified based on findings from the so called generator columns (Ghosh et al. 1998), which are considered the state of the art technique to establish saturated solutions of superhydrophobic organics such as PCBs. $C_{\text {free }}$ would otherwise be lower, which in turn would lead to an underestimation of $v_{\max }^{*}$ and a consequent overestimation of the predicted degradation times.

Generally, the less chlorinated PCB congeners were more rapidly metabolised, with strains LB400 and F113L::1180 showing similar performance, while strain F113rifpcb was less effective. Based on the experimental data we determined that the degradable fraction of Aroclor 1016 would be degraded after about 1000 years. Considerable uncertainty of the model prediction is associated with the initial 
aqueous concentration, with the maximum removal velocity and half-saturation constant, and especially with the bacterial cell density in soil and the mechanism of contaminant access. For an application as remediation technology, the time scale of PCB biodegradation determined in this study is rather long. The main obstacle for an effective degradation is - according to the model - that the main fraction of PCB is adsorbed to the soil matrix and is thus unavailable for the degradation process. The time period would be much shorter if the bacteria had strategies to take up PCB directly from the soil matrix, and not only, as assumed here, from soil pore water. In the environment, the diffusive mass transfer of PCB from soil matrix to bacteria may be enhanced by dissolved organic carbon (DOC) (Mayer et al. 2007), making also bacterial degradation in soil more effective. However, it was shown in this study that bacterial numbers decline during the degradation process, and the faster with faster degradation. Thus, even if PCB in soil was completely bioavailable, the strains investigated could not grow on this substrate, but require an alternative source for energy to survive. This makes rhizoremediation an attractive technique: Instead of technically supplying the degrader strains with substrate, root exudates may serve for this purpose, and indeed, the derivatives of strain F113 survived for more than half a year in the rhizosphere.

The data on degradation kinetics and bacterial numbers, and the information obtained on uncertainty, can be used for multimedia environmental modelling. Further investigations should be performed to evaluate degradation kinetics in contaminated soil. Efforts should especially focus on contaminant uptake mechanisms of microbes, and on. the heterogeneity of microbial populations in soil and rhizosphere. The methodology applied here might also be used to quantify microbial biodegradation of other contaminants.

\section{Acknowledgements}

This work has been funded by the European Commission within the FP 6 Integrated Project "ALARM" (GOCE-CT-2003-506675). The PCB-contaminated soil was kindly provided by T. Macek, Czech Academy of Sciences, Prague, Czech Republic. 


\section{References}

Abramowicz DA (1990) Aerobic and anaerobic biodegradation of PCBs - A review. Crit Rev Biotechnol 10(3): 241-251

Albro PW, Parker CE (1979) Comparison of the compositions of Aroclor 1242 and Aroclor 1016. J Chromatogr 169: 161-166

Aragno M (2005) The rhizosphere a hot spot of bacterial diversity? In T Satyanarayana T, Johri BN (eds.) Microbial Diversity Current Perspectives and Potential Applications. I.K. International Pvt. Ltd., New Dehli: 261-284

Barriault D, Sylvestre M (1993) Factors affecting PCB degradation by an implanted bacterial strain in soil microcosms. Can J Microbiol 39: 594-602

Bedard DL (1990) Bacterial transformation of polychlorinated biphenyls. Biodegradation 4: 370-388

Bedard DL, Unterman R, Bopp LH, Brennan MJ, Haberl ML, Johnson C (1986) Rapid assay for screening and characterizing microorganisms for the ability to degrade polychlorinated biphenyls. Appl Environ Microbiol 51(4): 761-768

Bopp LH (1986) Degradation of highly chlorinated PCBs by Pseudomonas strain LB400. J Ind Microbiol 1: 23-29

Brazil GM, Kenefick L, Callanan M, Haro A, de Lorenzo V, Dowling DN, O’Gara F (1995) Construction of a rhizosphere pseudomonad with potential to degrade polychlorinated biphenyls and detection of bph gene expression in the rhizosphere. Appl Environ Microbiol 61: 1946-1952

Bright DA, Grundy SL, Reimer KJ (1995) Differential bioaccumulation of non-ortho-substituted and other PCB congeners in coastal arctic invertebrates and fish. Environ Sci Technol 29(10): 2504-2512 
Brown JF Jr. (1994) Determination of PCB metabolic, excretion, and accumulation rates for use as indicators of biological response and relative risk. Environ Sci Technol 28(13): 2295-2305

Cornish-Bowden A (1995) Fundamentals of enzyme kinetics. Portland Press, London, UK, pp 343

Criddle CS (1993) The kinetics of cometabolism. Biotechnol Bioeng 41: 1048-1056

Dalton H, Stirling DI (1982) Co-metabolism. Philos T Roy Soc B 297: 481-496

Delany IR, Walsh UF, Ross I, Fenton AM, Corkery DM, O'Gara F (2001) Enhancing the biocontrol efficacy of Pseudomonas fluorescens $\mathrm{F} 113$ by altering the regulation and production of 2,4diacetylphloroglucinol - improved pseudomonas biocontrol inoculants. Plant Soil 232: 195-205

Demnerova K, Mackova M, Spevakova V, Beranova K, Kochankova L, Petra Lovecka P, Ryslava E, Macek T (2005) Two approaches to biological decontamination of groundwater and soil polluted by aromatics - Characterization of microbial populations. Int Microbiol 8: 205-211

Dowling DN, Pipke R, Dwyer DF (1993) A DNA module encoding bph genes for the degradation of polychlorinated biphenyls (PCBs). FEMS Microbiol Lett 113: 149-154

European Commission (1996) Technical Guidance Document in Support of Commission Directive 93/67/EEC on Risk Assessment for new Notified Substances and Commission Regulation (EC) No 1488/94 on Risk Assessment for Existing Substances. Luxembourg, Office for Official Publications of the European Communities

Fetter CW (1994) Applied hydrogeology, 3rd ed. Prentice-Hall Inc., Englewood Cliffs, NJ, USA, pp 691

Fletcher JS, Hedge RS (1995) Release of phenols by perennial plant roots and their potential importance in bioremediation. Chemosphere 31: 3009-3014 
Fletcher JS, Donnelly PK, Hegde RS (1995) Biostimulation of PCB-degrading bacteria by compounds released from plant roots, pp 131-136. In Hinchee RE, Anderson DB, Hoeppel RE (eds) Bioremediation of recal-citrant organics. Battelle Press, Columbus, $\mathrm{OH}$

Frame GM, Cochran JW, Bowadt SS (1996) Complete PCB congener distributions for 17 Aroclor mixtures determined by 3 HRGC Systems optimised for comprehensive, quantitative, congenerspecific analysis. J High Resol Chromatogr 19: 657-668

Furukawa K, Matsumura F (1976) Microbial metabolism of polychlorinated biphenyls - Studies on relative degradability of polychlorinated biphenyl components by Alcaligenes sp. J Agr Food Chem 24: $251-256$

Gibson DT, Cruden DL, Haddock JD, Zylstra GJ, Brand JM (1993) Oxidation of polychlorinated biphenyls by Pseudomonas sp. LB400 and Pseudomonas pseudoalcaligenes KF707. J Bacteriol 175: 4561-4564

Ghosh U, Weber AS, Jensen JN, Smith JR (1998) Dissolved PCB congener distribution in generator column solutions. Water Res 32: 1373-1382

Horvath RS (1972) Microbial co-metabolism and the degradation of organic compounds in nature. Bact Rev 36(2): 146-155

Karlson U, Uotila JS, Jacobsen CS (1995) Use of plants with inoculated microorganisms for soil cleaning (in Danish). Patent Office, Copenhagen, 25 January 1995. Pat. No. PR 173559

Legind CN, Karlson U, Burklen JG, Reichenberg F, Mayer P (2007) Determining chemical activity of (semi)volatile compounds by headspace solid phase microextraction. Anal Chem 79, 2869-2876

Leigh MB, Prouzova P, Mackova M, Macek T, Nagle DP, Fletcher JS (2006) Polychlorinated biphenyl (PCB)-degrading bacteria associated with trees in a PCB-contaminated site. Appl Environ Microbiol 72(4): 2331-2342 
Masai E, Yamada A, Healy JM, Hatta T, Kimbara K, Fukuda M, Yano K (1995) Characterization of Biphenyl Catabolic Genes of Gram-Positive Polychlorinated Biphenyl Degrader Rhodococcus sp. Strain RHA1. Appl Environ Microbiol 61(6): 2079-2085

Mayer P, Fernqvist MM, Christensen PS, Karlson U, Trapp S (2007). Enhanced diffusion of polycyclic aromatic hydrocarbons in artificial and natural aqueous solutions. Env Sci Technol 41, published on line 2 Aug. 2007, DOI: 10.1021/es070495t.

McFarland VA, Clarke JU (1989) Environmental occurrence, abundance, and potential toxicity of PCB congeners considerations for a congener-specific analysis. Environ Health Persp 81: 225-239

Meijer SN, Ockenden WA, Sweetman A, Breivik K, Grimalt JO, Jones KC (2003) Global distribution and budget of PCBs and HCB in background surface soils Implications for sources and environmental processes. Environ Sci Technol 37 (4): 667-672

Naseby DC, Lynch JM (1999) Effects of Pseudomonas fluorescens on ecological functions in the pea rhizosphere are dependent on pH. Microbiol Ecol 37: 248-256

Olson PE, Fletcher JS, Philp PR (2001) Natural attenuation/phytoremediation in the vadose zone of a former industrial sludge basin. Environ Sci Poll Res 4: 243-249

Reichenberg F, Mayer P (2006) Two complementary sides of bioavailability. Accessibility and chemical activity of organic contaminants in sediments and soils. Environ Toxicol Chem 25 (5): 12391245

Rein A, Bittens M (In Preparation) Identification of environmentally relevant PCB congeners Considerations for a multimedia risk assessment in an uncertain and variable environment

Ryslava E, Krejcik Z, Macek T, Novakova H, Demnerova K, Mackova M (2003) Study of PCB degradation in real contaminated soil. Fresen Environ Bull 12(3): 296-301 
Safe SH (1994) Polychlorinated-biphenyls (PCBs) - Environmental impact, biochemical and toxic responses, and implications for risk assessment. Crit Rev Toxicol 24: 87-149

Seeger M, Timmis KN, Hofer B (1995) Conversion of chlorobiphenyls into phenylhexadienoates and benzoates by the enzymes of the upper pathway for polychlorobiphenyl degradation encoded by the bph locus of Pseudomonas sp. strain LB400. Appl Environ Microbiol 61: 2654-265

Seto M, Kimbara K, Shimura M, Hatta T, Fukuda M, Yano K (1995) A Novel Transformation of Polychlorinated Biphenyls by Rhodococcus sp. Strain RHA1. Appl Environ Microbiol 61(12): 45104513.

Shanahan P, O'Sullivan DJ, Simpson P, Glennon JD, O'Gara F (1992) Isolation of 2,4diacetylphloroglucinol from a fluorescent pseudomonad and investigation of physiological parameters influencing its production. Appl Environ Microbiol 58: 353-358

Simons M, Vanderbij AJ, Brand I, de Weger LA, Wijffelman CA, Lugtenberg BJJ (1996) Gnotobiotic system for studying rhizosphere colonization by plant growth-promoting Pseudomonas bacteria. Mol Plant-Microbe Interact 9: 600-607

Sitte P, Ziegler H, Ehrendorfer F, Bresinsky A (1991) Lehrbuch der Botanik für Hochschulen. 33rd ed., Gustav Fischer, Stuttgart, 1048 pp

Trapp S, Karlson U (2001) Aspects of phytoremediation of organic pollutants. J Soils Sed 1: 37-43

Trapp S, Ücisik AS, DelChicca Romano P, Larsen M (2007) The role of plants and bacteria in phytoremediation - kinetic aspects, pp. 41-49. In Heipieper, HJ (Ed.), Bioremediation of soils contaminated with aromatic compounds. Springer, Berlin, Germany 
Unterman R, Bedard DL, Brennan MJ, Bopp LH, Mondello FJ, Brooks RE, Mobley DP, McDermott JB, Schwartz CC, Dietrich DK (1988) Biological approaches for polychlorinated biphenyl degradation, pp. 253-269. In Omenn GS (ed.) Environmental biotechnology reducing risks from environmental chemicals through biotechnology. - Plenum Press, New York, N.Y.

Villacieros M, Power B, Sanchez-Contreras M, Lloret J, Oruezabal RI, Martin M, Fernandez-Pinas F, Bonilla I, Whelan C, Dowling DN, Rivilla R (2003) Colonization behaviour of Pseudomonas fluorescens and Sinorhizobium meliloti in the alfalfa (Medicago sativa) rhizosphere. Plant Soil 251: 47-54

Villacieros M, Whelan C, Mackova M, Molgaard J, Sanchez-Contreras M, Lloret J, Aguirre de Carcer D, Oruezabal RI, Bolanos L, Macek T, Karlson U, Dowling DN, Martin M, Rivilla R (2005) Polychlorinated biphenyl rhizoremediation by Pseudomonas fluorescens F113 derivatives, using a Sinorhizobium meliloti nod system to drive bph gene expression. Appl Environ Microbiol 71: 26872694

Walton BT, Anderson TA (1990) Microbial degradation of trichloroethylene in the rhizospheres. Potential application to biological remediation of waste sites. Appl Environ Microbiol 56: 1012-1016

Yee DC, Maynard JA, Wood TK (1998) Rhizoremediation of trichloroethylene by a recombinant, rootcolonizing Pseudomonas fluorescens strain expressing toluene ortho-monooxygenase constitutively. Appl Environ Microbiol 64: 112-118 


\section{FIGURE LEGENDS}

Fig. 1: Degradation of PCB 4 with strain F113L::1180: results of in vitro experiments and Monod modelling. a) contaminant concentration versus time, b) bacterial mass per litre versus time and c) removal velocity versus concentration. Neg. control: negative control.

Fig. 2: Bacterial decline rate $k_{\text {death }}$ (active cells) as a function of maximal removal velocity $v_{\text {max }}^{*}$ a) mean values specific for strain LB400 and F113L::1180 and b) mean, minimum and maximum for all experiments. N: number of values.

Fig. 3: Bacterial plate counts in the willow rhizosphere of the mesocosm experiment as a function of time, a) total heterotrophic bacteria on 10\%TSA, b) F113 derivatives on selective SArif medium.

Fig. 4: Simulated breakdown with strain F113L::1180 in soil using willow plants, under consideration of uncertainty for rhizoremediation. a) to c): individual PCB congeners, d) to f): biodegradable fraction of Aroclor mixtures. 